\title{
Civil interventions for tackling MTIC fraud: a UK perspective
}

\author{
by Steven Pope and Roderick Stone
}

$\mathrm{M}$ issing trader intra community or MTIC fraud has been a problem across the European Union for over 10 years, and much has been written about its effects and how best to tackle it. So what is MTIC fraud and why does it pose such a challenge to tax administrations across the EU?

In order to understand how MTIC fraud is perpetrated, it is important first to understand how the VAT system functions. VAT is a consumption tax, operating via a fractionated collection system, the VAT on the value added at each stage of a supply chain is paid to the tax authority by VAT-registered businesses. When a business sells goods, the supplier will charge VAT (output tax) on the price of the goods. It will normally deduct from the output tax any VAT incurred on its purchases (input tax) relating to the supply of the goods and pay the net amount to the tax authority. This way the cost of VAT is only borne by the final consumer of the supply.

VAT is charged by all Member States of the EU. However, transactions between VAT-registered persons in differing Member States (intra community transactions) are exempt from VAT (zero rated). The customer is responsible for payment of the VAT on its intracommunity purchases but retains the normal right to deduct input tax. In these circumstances the customer effectively has in its hands VAT-free goods (or services).

MTIC fraud exploits this zero-rated supply across national boundaries as a means for stealing revenues from national states (carousel fraud) or creating a VAT debt to be used as a subsidy for undercutting legitimate supplies (acquisition fraud). The fraud is perpetrated when a business obtains a VAT registration number in one EU Member State, often with the sole intention of purchasing goods VAT-free from a business in another EU Member State and then selling them on to another business at a VAT-inclusive price but without paying the VAT charged to their tax authority.

In many cases the fraudulent business "disappears" immediately. Such businesses are often called "missing traders." In some circumstances, the registered business will keep on trading and building up a debt until the tax authority finds them and takes action to close down the company. Such businesses are often referred to as "defaulting traders."
MTIC carousel fraud is a financial fraud and not a commodity based fraud, carried out with the sole aim of submitting a fraudulent VAT repayment claim (or to reduce the amount of VAT that a business pays to the national tax administration). Goods are typically imported VAT-free from another EU Member State and then passed through a chain of contrived transactions before being reexported. As the goods are being exported, the goods will be sold VAT-free, thus creating a large VAT repayment for the exporting trader, (known as a broker); the repayment based on the VAT paid to its supplier. The transaction chains are contrived in a way that ensures that at or near the beginning of the transaction chain one of the traders will 'go missing' to avoid paying VAT to the tax authority. The goods will usually pass through a series of VAT registered businesses, (known as buffers) to distance the broker from the missing trader before being re-exported. If the VAT repayment return submitted by the exporter is paid, it crystallises the unpaid paper debt accumulated by the missing trader.

Figure 1 gives an illustration of a typical MTIC chain showing both the movement of money and invoiced transaction. In an MTIC carousel fraud, the same goods can be repeatedly imported, sold and then exported, each time creating a repayment claim, hence the term carousel. In some cases there may be no goods at all, simply a series of paper transactions. As a rule, all of the traders within the supply chain will be aware of the fraud and working actively to facilitate its operation.

MTIC acquisition fraud differs from carousel fraud in that the goods are eventually sold for retail consumption. In this case, the VAT charged but not paid to the tax authority by the missing or defaulting trader forms the profit, enabling fraudsters to undercut genuine trade.

The impact of MTIC fraud on tax receipts can be substantial, particularly carousel fraud, which because of its contrived nature has no theoretical limit. Since 1999, the government has published estimated losses from MTIC fraud in the Pre-Budget Review, (PBR) which is published in the autumn. The levels of fraud peaked in 2005/06, (see figure 2) where losses were estimated at between $£ 3.0$ billion and $£ 4.0$ billion. Since then, a combination of both legislative and operational changes has enabled the UK to reduce losses by at least 38 per cent. 


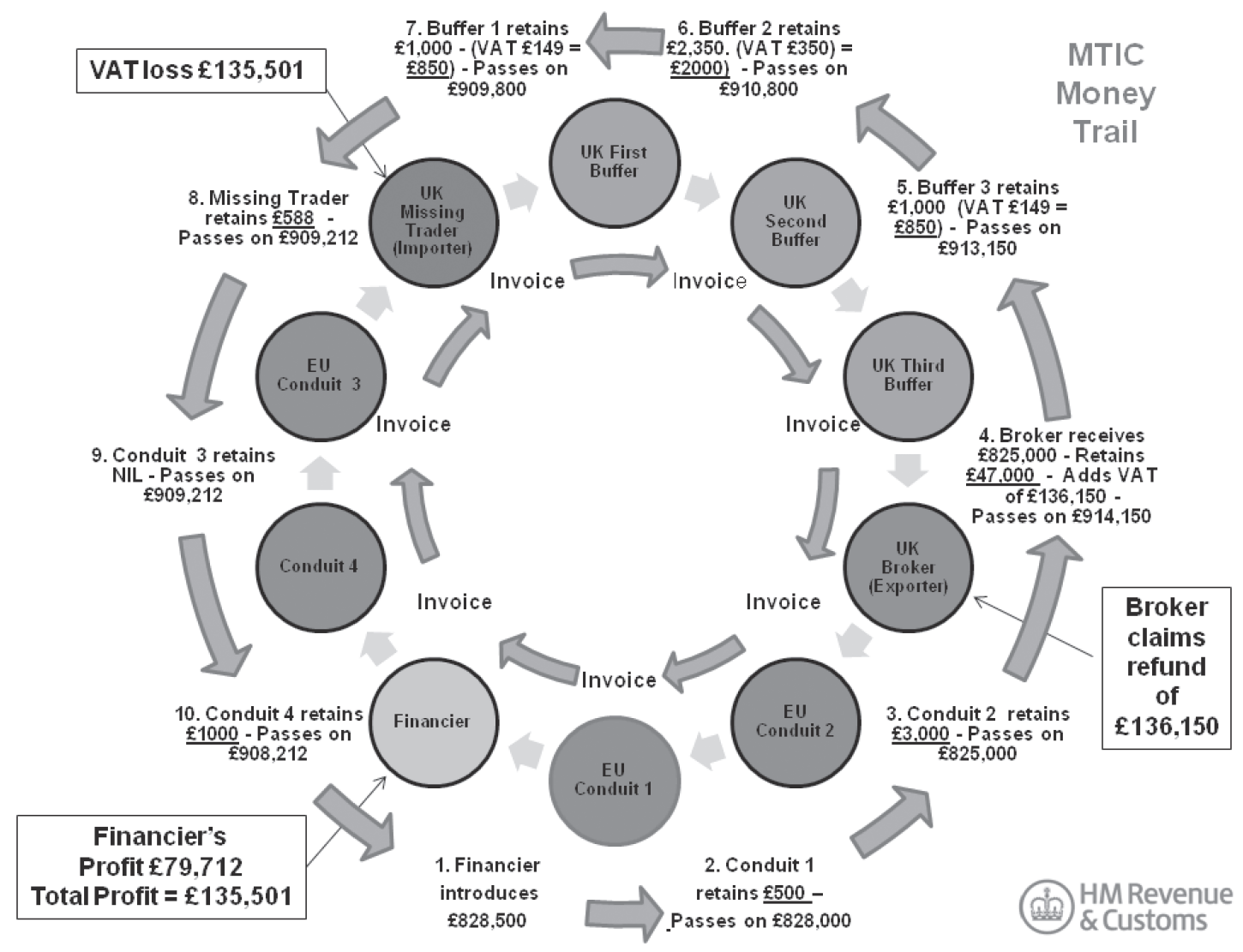

Figure 1: MTIC carousel fraud

Since its inception, the MTIC strategy has consisted of a multi-faceted approach combining both criminal and civil measures to tackle the fraud.

HMRC has maintained a successful prosecution policy focusing on those that orchestrate the fraud. This approach sends out the message that such criminal activity will be robustly challenged, and with the high level of successful prosecutions will offer a strong deterrent both now and in the future.

However, criminal prosecution is not the answer to everything and must be supplemented with civil strategies that tackle the economy of participation in fraud and deter

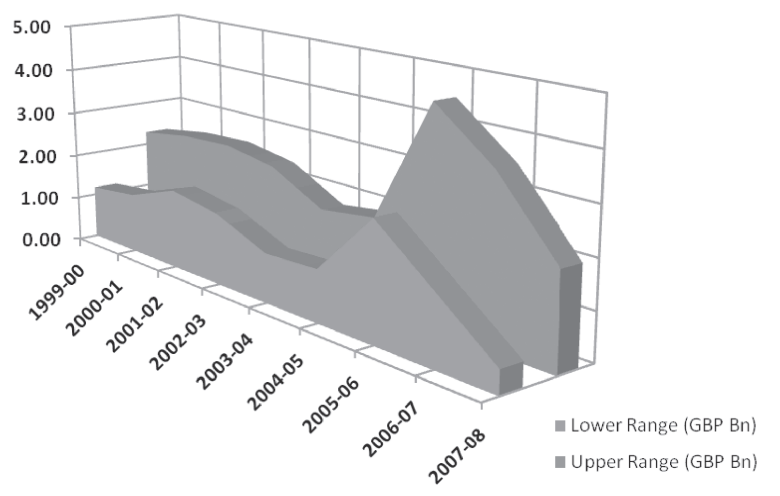

Figure 2: MTIC losses as published at PBR those that may consider that MTIC fraud may be a profitable enterprise. With this in mind, HMRC has a range of interventions to mitigate the impact on tax receipts where evidence of abuse can be demonstrated:

- denying input tax;

- denying the zero rating of intra community transactions;

- imposing financial penalties;

- taking action to recover lost revenue.

This approach has been refined and developed as a result of case judgments emanating from the UK High Court and the European Court of Justice (ECJ). So if there is such a blatant attack on the VAT system, why have not HMRC and other tax administrations found a permanent solution to the problem?

\section{LEGISLATIVE FRAMEWORK}

The framework for the VAT system within the EU is set out in EU Directive 2006/112EC, known as the "Principal VAT Directive." This is a recast of the Sixth VAT Directive of 1977 , bringing together all amendments since 1977 in one single piece of legislation.

This legislation provides for a common system of VAT with a unified basis for assessment that respects the principles of proportionality, legal certainty and fiscal 
neutrality. Many tax administrations and professionals still refer to the articles of the Sixth VAT Directive.

Article 17 of the Sixth VAT Directive provides a taxable person with the fundamental right to deduct input tax, therefore declaring to the tax authority that a commercial transaction has taken place. This right to deduct must be exercised immediately in respect of all the VAT charged on the cost components (see C-62/93 BP Supergas [1995] ECR I-1883, para 18, and joined cases C-118/98 to C147/98 Gabalfrisa and Others [2000] ECR I-1577, para 43).

Tax administrations aim to ensure that the right amount of tax is paid by the right person at the right time. A business must declare all the output tax due on its sales and the input tax incurred on its supplies and pays the net amount to the tax authority.

It is reasonable that an honest taxable person is not liable if his supplier fails to pay over any tax charged and his fundamental right to deduct any tax paid on his purchases is unaffected. However, in organised criminal attacks on the VAT system, such as MTIC fraud, the challenge for a tax administration is how to tackle such abuse in a proportionate manner which penalises the non-compliant without penalising the honest taxpayer, or the requirement for legal certainty.

HMRC's approach to this challenge has been to explore both operational and legislative measures which focus on the threat to the revenue whilst at the same time ensuring that legitimate businesses can operate on a level playing field.

\section{IS TRADING IN CONTRIVED MTIC FRAUD SUPPLY CHAINS A REAL ECONOMIC ACTIVITY?}

In May 2002 the UK began to deny input tax claims submitted by UK exporters on the basis that, where there were circular supply chains, the goods were carouselled and did not conclude in sales to final consumers. There was no commercial rationale behind the transactions, ergo no economic activity. HMRC argued that where the only intention was to commit fraud then such transactions did not fall within the scope of the Sixth VAT Directive.

This approach was challenged by a number of brokers whose input tax claims had been denied, eventually reaching the ECJ (see C-354/03, C-355/03 and C-484/03, Optigen Ltd, Fulcrum Electronics Ltd, and Bond House Systems Ltd $v$ Commissioners of Customs and Excise [2006] ECR I-483). The question put to the ECJ was whether transactions constituting part of a fraudulent scheme set up by others qualified as economic activities within the meaning of Article 4(2) of the Sixth Council Directive 77/388/EEC.

In its judgment of January 12, 2006 the ECJ found that transactions within a fraudulent trade are within the scope of the Directive:
"The right to deduct input tax of a taxable person who carries out such transactions cannot be affected by the fact that in the chain of supply of which those transactions form part another prior or subsequent transaction is tainted by a VAT fraud, without that taxable person knowing or having means of knowledge of the fraud" [emphasis added].

The initial reaction of fraudsters was that this was a defeat for the UK and consequently, levels of fraud increased dramatically (see figure 3). However, in giving its judgment the ECJ qualified it on the basis that the taxpayer maintained a fundamental right to deduct so long as they did not know or did not have the means to know that they were involved in transactions linked to fraud.

HMRC recognised that if they were to deny the input tax claims of those that facilitated and profited from the fraud then they would have to demonstrate that the claimant knew or should have known that they were trading in fraudulent supply chains. This came to be known as the "knowledge test". Such an approach is highly effective, albeit resource intensive, requiring the painstaking collection and assessment of evidence to support a denial.

\section{THE KNOWLEDGE TEST AND JOINT AND SEVERAL LIABILITY}

Whilst challenging the validity of input tax claims is an important element of HMRC's civil interventions, it is not the only one. Consideration was also given as to how to tackle the theft of VAT by the missing trader. HMRC had already gained enough evidence to show the contrived nature of transactions linked to fraud and the initial theft of the VAT by the missing trader. The question then arose as to whether traders that knowingly and consistently traded with missing traders could be made jointly and severally liable for any stolen VAT.

\section{Joint and several liability}

In the 2003 Finance Act, the UK introduced the concept of joint and several liability into the VAT Act 1994 (s 77A VATA 1994). The legislation focuses on what, at the time, were the fraudsters' preferred commodities, namely mobile phones and computer chips, and provides that a business can be made jointly and severally liable for stolen VAT if it had reasonable grounds to suspect that VAT would go unpaid anywhere in its transaction chains.

\section{Legal challenge}

As with non-economic activity HMRC's approach was challenged in the courts, again being ultimately referred to the ECJ. The appellant in this case was a group called the Federation of Technological Industries (FTI) (Case C384/04, Federation of Technological Industries and Others [2006] ECR I-4191) which represented some of the brokers submitting large VAT repayment claims. 
In May 2006, the ECJ issued its findings supporting the UK's approach to joint and several liability:

"Allowing a Member State to enact legislation, such as that in issue in the main proceedings, which provides that a taxable person, to whom a supply of goods or services has been made and who knew, or had reasonable grounds to suspect, that some or all of the value added tax payable in respect of that supply, or of any previous or subsequent supply, would go unpaid, may be made jointly and severally liable, with the person who is liable, for the payment of tax" [emphasis added].

The ECJ made it clear that any national legislation such as joint and several liability must comply with EU law in that it must be applied in a manner which reflects the gravity of any abuse and must offer legal certainty:

"Such legislation must, however, comply with the general principles of law which form part of the Community legal order and which include, in particular, the principles of legal certainty and proportionality" [emphasis added].

Both Bond House and FTI sent clear messages to tax administrations that in tackling fraud they must take care to act proportionally and provide taxpayers with legal certainty. However, the ECJ also sent a clear message to knowing participants in fraudulent transaction chains that they could not benefit from the fraud by relying on EU VAT rules.

\section{Kittel}

It is accepted practice that businesses must apply corporate governance processes to protect themselves from financial exposure. The extent of any corporate governance is determined by the level of the risk.

The decisions in Bond House and FTI (joint and several liability) reaffirmed HMRC's expectation of appropriate corporate governance, including due diligence/know your customer/supplier checks, and proper risk management. This message was reinforced in a later ECJ decision in the cases of Kittel \& Recolta, a co-joined Belgian case published in July 2006 (C-439/04 and C-440/04, Kittel v Belgian State and Belgian State v Recolta Recycling [2006] ECR I-6161). Kittel has become very much the model by which tax administrations verify the veracity of input tax claims suspected of being linked to fraud.

The case itself concerned a company called Computime which dealt in mobile phones and computer chips (Mr Kittel was the company receiver). Computime traded in computer parts which the Belgian authorities discovered were part of an MTIC carousel fraud. As a result, they concluded that Computime had knowingly participated in MTIC carousel fraud and declared the contracts between Computime and their suppliers as void, effectively denying their input tax claim.

The ECJ was asked whether, if a trader entered into a contract in good faith that was subsequently declared void under national legislation, EU legislation overruled national legislation, therefore maintaining the taxpayer's entitlement to deduct input tax under Article 17 of the Sixth VAT Directive. The court was also asked whether the answer would be different if the contract was declared void because of fraudulent evasion of VAT.

In its judgment the ECJ stated that so long as a taxpayer had taken all reasonable steps, then they could rely on Article 17 to recover their input tax:

"It is apparent that traders who take every precaution which could reasonably be required of them to ensure that their transactions are not connected with fraud, be it the fraudulent evasion of VAT or other fraud, must be able to rely on the legality of those transactions without the risk of losing their right to deduct the input VAT (see, to that effect, Case C384/04, Federation of Technological Industries and Others [2006] ECR I-4191, para 33).”

The ECJ however qualified this in that no entitlement stood if the claimant themselves perpetrated fraud. In those circumstances the tax authorities could not only deny any input tax but could reclaim any input tax previously paid to the claimant:

"By contrast, the objective criteria which form the basis of the concepts of supply of goods effected by a taxable person acting as such - and economic activity - are not met where tax is evaded by the taxable person himself (see Case C-255/02 Halifax and Others [2006] ECR I- 1609, para 59).

"Where the tax authorities find that the right to deduct has been exercised fraudulently, they are permitted to claim repayment of the deducted sums retroactively (see, inter alia, Case 268/83 Rompelman [1985] ECR 655, para 24; Case C-1 10/94 INZO [1996] ECR I-857, para 24; and Gabalfrisa and Others [2000] ECR I-1577, para 46)."

The ECJ in its judgment went on to state that anyone who knew or should have known that they were trading in fraudulent transaction chains would be regarded, for VAT purposes, as a participant in the fraud, regardless of whether they profited from the fraud or not:

"In the same way, a taxable person who knew or should have known that, by his purchase, he was taking part in a transaction connected with fraudulent evasion of VAT must, for the purposes of the Sixth Directive, be regarded as a participant in that fraud, irrespective of whether or not he profited by the resale of the goods.

"That is because in such a situation the taxable person aids the perpetrators of the fraud and becomes their accomplice. In addition, such an interpretation, by making it more difficult to carry out fraudulent transactions, is apt to prevent them. As the court has already observed, preventing tax evasion, avoidance and abuse is an objective recognised and encouraged by the Sixth Directive (see Joined Cases C-487/01 and C-7/02 Gemeente Leusden and Holin Groep BV [2004] ECR I-5337, para 76).

"Community law cannot be relied on for abusive or fraudulent ends (see, inter alia, Case C-367/96 Kefalas 


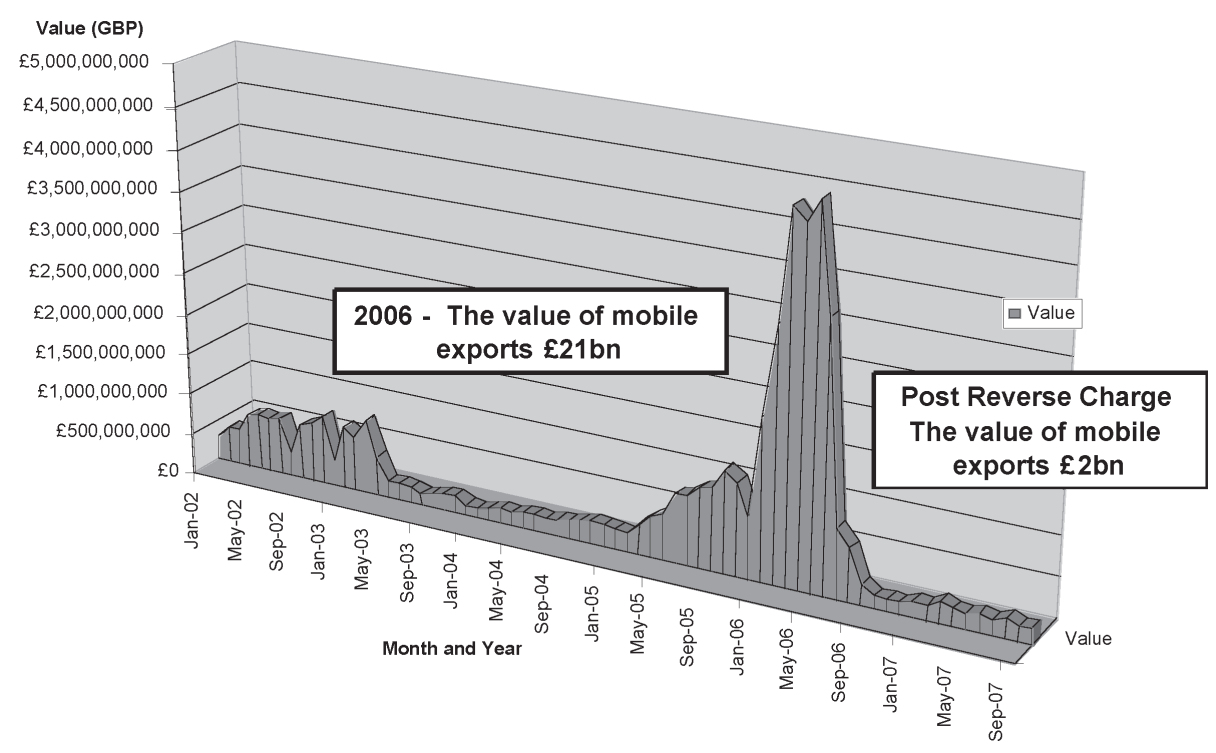

Figure 3: The changes in levels of fraud in reaction to legislative developments

and Others [1998] ECR I-2843, para 20; Case C373/97 Diamantis [2000] ECR I-1705, para 33; and Case C-32/03 FiniH [2005] ECR I -1599, para 32).”

The ECJ stated that the decision to deny input tax recovery lies squarely with the national administration:

"It is a matter for the national court to refuse to allow the right to deduct where it is established, on the basis of objective evidence, that that right is being relied on for fraudulent ends (see FiniH, para 34)."

Kittel had built on the abuse argument first examined in the Bond House judgment and echoed in FTI, clearly stating what the taxpayer could expect with regard to legal certainty and proportionality from their respective tax administrations. However, it set out the parameters under which taxpayers may rely on the VAT Directive to protect them. The knowledge test has been used extensively in the UK and across the EU and has become an important part of the EU's efforts to combat MTIC fraud.

\section{IS FOCUSING ON BEHAVIOUR THE ONLY OPTION?}

The measures in this article so far have focused on the behaviours of those perpetrating, profiting from or facilitating the fraud. However, HMRC has also looked across the piece at other means by which the fraud can be tackled. In 2007, HMRC introduced legislation which focused on the mechanism by which VAT could be stolen.

Any change to the general rules of the VAT system is not to be taken lightly. Member States considering such action have to obtain a derogation from EU law supported by all 26 fellow Member States. On June 1, 2007, having secured a derogation, the UK introduced a domestic reverse charge in respect of wholesale trade in computer chips and mobile phones.
So what is a reverse charge, and why mobile phones and computer chips?

A reverse charge transfers the obligation to pay output tax from the supplier to the customer but the customer retains its entitlement to deduct VAT on its purchases. This means that in effect at each stage a business is in a net nil tax situation and the opportunity to commit MTIC fraud is removed. A reverse charge only applies to business to business transactions and the normal accounting rules apply on sales to final consumers. As a consequence it is no longer possible for:

- the missing trader to disappear with the VAT paid to him by his customer but owed to HMRC;

- traders to divert the VAT due to be paid by their suppliers through third-party payments; and

- the exporter to claim a VAT repayment from HMRC.

These commodities were chosen because they were the goods most commonly used in UK carousel fraud supply chains. The effect of this legislative change has been to stop MTIC carousel fraud in mobile phones and computer chips. The reverse charge and the application of the knowledge test to tackle all MTIC style trade maintains a downward pressure on MTIC fraud and revenue losses.

You may ask why, if the reverse charge is so effective, HMRC does not apply it to all goods. The answer is that it is only appropriate in specific circumstances. Under the fractionated collection system VAT is collected on the value added at each stage in the supply chain, mitigating the impact of fraud at the point of sale to the final consumer. For all its imperfections the VAT system is generally a much more effective system for collection of revenue than a sales/purchase tax levied at the retail stage. 


\section{SUMMARY}

The article has shown how levels of fraud changed in response to decisions by the courts or legislative changes introduced by HMRC. The impact on receipts can be considerable if not tackled at the earliest opportunity.

The UK has carefully analysed every element of the fraud and sought ways to tackle the fraud at specific points. This approach has enabled HMRC to demonstrate considerable success in reducing levels of fraud and ultimately the levels of losses.

The role of the courts has been a major factor not only in the approach of tax administrations but also in the tactics adopted by MTIC fraudsters. The courts have indicated that any action taken by a tax administration must be proportionate and offer the taxpayer legal certainty. However, taxpayers must also bear responsibility for losses if they do not take appropriate care and choose to turn a blind eye for the sake of profit.

No single measure will solve the problem of MTIC fraud, but having a combination of carefully planned measures in place, backed up with the continuing monitoring of risk, will keep levels of fraud to a minimum.

Steven Pope and Roderick Stone

HM Revenue \& Customs. 